\title{
Study Of The Implementation Of Regulations In The Framework For Sustainable Transportation
}

\author{
Juanita' B. Kombaitan, Iwan P. Kusumantoro and Heru Purboyo Hidayat Putro
}

\begin{abstract}
Here discussed aspects of existing regulation in Indonesia related to the implementation of traditional modes. The main aim of the research is to show the importance of regulatory aspects and the regulatory framework for the implementation of traditional transportation as a form of protection. Approach through in-depth interviews with relevant stakeholders and studies of regulations applied at the central and regional levels. Result research that the right regulatory framework is important. The central regulation is a legal reference to the application of rules in the regions. While the Local governments play a primary role in the recognition, protection, utilization and preservation of traditional modes.
\end{abstract}

Index Terms - organizing, regulation, sustainable transportation, traditional mode.

\section{INTRODUCTION}

$\mathbf{T}$ he important role of non-motorized vehicles is basic mobility, affordable

transportation, access to motorized modes, physical fitness and leisure.[1]. The use of non-motorized modes is to reduce pollution emissions and to improve public health. [2]. It is known that transportation activities in Indonesia contribute $23 \% \mathrm{CO} 2$ emissions with the largest energy consumption are on the road as much as $90.7 \%$. [3]. Horse chart usage can reduce the use of gasoline 2,065,717.50 liters/year and decrease $\mathrm{CO} 2$ from short range transportation activities $(4,792$ $\mathrm{CO} 2$ ton / year).[4]. Therefore, horse charts as an alternative non-motorized vehicle can be relied upon to reduce energy consumption.

However, in Indonesia the implementation of traditional vehicles becomes a problem in itself. Organizing traditional mode, in some areas, there are acceptance and rejection related

Juanita is with the School of Architecture, Planning, and Policy Development, Bandung Institute of Technology, 40132, Bandung, West Java, Indonesia and Department of Civil Engineering, Universitas Muhammadiyah Purwokerto, 53182, Purwokerto, Central Java, (e-mail: juanitamstr@gmail.com)

B. Kombaitan is with the School of Architecture, Planning, and Policy Development, Bandung Institute of Technology, 40132, Bandung, West Java, Indonesia

I.P. Kusumantoro is with the School of Architecture, Planning, and Policy Development, Bandung Institute of Technology, 40132, Bandung, West Java, Indonesia

H.P.H. Putro is with the School of Architecture, Planning, and Policy Development, Bandung Institute of Technology, 40132, Bandung, West Java, Indonesia. aspects of legality and operational modes. The commonly used traditional mode is rickshaw and horse cart. For example, in DKI Jakarta since 1992, horse chart operates in Monas as a tourist transport. The change of Governor in 2007 until 2016, the banned the horse chart operating in Jakarta [5], from 1967 to 2017 was banned rickshaws streets of the capital.[6]. Now, the new Government of DKI Jakarta reactivates its operations. Unlike the case in the Special Region of Yogyakarta received and the vehicle becomes an icon city tour. The operations of traditional vehicles are vulnerable to regulations in a region.

The study aims to explore the importance of proper rules and regulations on the operation modes. This study highlights the regulation of traditional implementation because regulation as a protective tool establishes operational rules for service providers and regulators, and ensures standards implemented. Regulation is also beneficial for the public interest and the application of government policies implemented effectively and efficiently. The study describes the results of in-depth interviews of stakeholders and policies of the central and regional governments related to the implementation of traditional transportation. The depth interview and policy aspect based on the regulations applied in the study area. The aspect arranged to sustainability of traditional modes within the framework of sustainable transport. Research results are expected to provide input on the implementation of traditional transportation in other regions.

\section{The Definition of Transportation Traditional}

In Indonesia, non-motorized vehicles defined as vehicles driven by human and animal power.[7] and [8]. These vehicles, common in Indonesia besides bicycles are rickshaw and horse cart. Bicycles have not legality issues, but some areas to rickshaw and horse carts are a debate on operations and legality. Some parts of Indonesia, there is development pedal rickshaw modified into a motorized rickshaw. Related non-motorized vehicles modified motorized vehicle called bentor. It observed from the Law no 22 of 2009 article 122 paragraph one states non-motorized vehicle drivers prohibited vehicles withdrawn by motor vehicle with the speed of endangering the safety. Speed regulation a strong factor where higher speeds will impact pedestrians/residents. [9]. Addition, non-motorized vehicles assembled or modified into motor vehicles shall meet vehicle eligibility requirements and testing. Government Regulation No. 55 of 2012 on vehicles described for motor vehicles must meet the technical requirements of article 6 and the requirements of road worthy article 64. 
The definition of traditional transportation shall be nonmotorized vehicles with the driving force of persons or animals. Traditional transportation categorized into informal transportation systems. It based on the informal organization and the use of non-motorized technology.[10]. For example, horse chart Yogyakarta has different characteristics compared to other regions in Indonesia. Differences are in design and wheel andong and cidomo presented in Fig. 1.

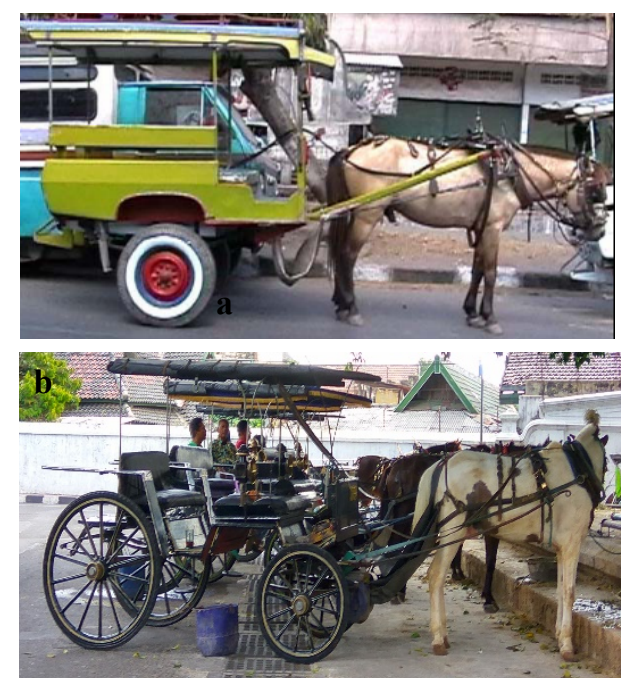

Fig.1. Differences design and wheel andong and cidomo (source: a.[4], b. research documents, 2018)

Andong has four wheels, other areas such as delman, bendi, dokar or cidomo in Mataram which consists of two wheels. Cidomo wheels made of two car tires, while the andong made of wood lined with tire wheels.

\section{SUSTAINABLE TRANSPORTATION FRAMEWORK}

The purpose of sustainable transportation is to ensure environmental, social and economic considerations, taken into account decisions affecting transport activities [11], including involving long-term, indirect and non-market impacts. [12]. The Council of Transport Ministers of the European Union: sustainable transportation as a system that is 1) Enabling basic access and development needs of individuals, enterprises and communities safely and consistently to human health and ecosystems, and promising equality and between successive generations; 2) Affordable, operating fair and efficient, offering a choice of modes of transport, and supporting a competitive economy, as well as a balanced regional development. [13].

\section{Methodology}

\section{A. Study area}

In Indonesia, it reviewed the area of the province of Yogyakarta Special Region is the smallest province after DKI Jakarta Province. The province took because of local government and community acceptance the existence of traditional vehicles. Andong is a typical Yogyakarta vehicle and a tourist icon. Andong has a uniqueness in the design, wheels and coachman using typical Javanese clothes. Andong pulled by one or two horses.[14]. There is a community accommodates traditional transportation operations. The province consists of Kulonprogo, Bantul, Gunungkidul, Sleman and Yogyakarta. [15]. Yogyakarta Province has 132 attractions [15], the number of foreign tourists in 2016 reached 511,545 people while the domestic tourists $20,933,798$ tourists, bringing the total visitors $21,445,343$ tourists. The most visited cultural tourism is Yogyakarta Palace 34,25\% (domestic tourists) and 25,67\% (foreign tourists). [16].

\section{B. Method of research}

The research method used through in-depth interviews with snowball sampling techniques conducted on relevant stakeholders. The interviews conducted with the Head of Section Transportation and Staff of the Yogyakarta City Transportation Agency, Chairperson of Pordasi (Equestrian Sports Union All Indonesia) of Yogyakarta Province, Chair of the association of horse cart drivers in the Special Region of Yogyakarta, and the coachmen who were members of the association. In-depth interviews aim to explore the implementation and policies of local governments and the role of the community in operations. Besides, the policy aspect is carried out through the collection of regulatory documents at the central and regional levels regarding traditional modes. These aspects grouped into aspects of implementation, traffic safety, traffic planning and management, and modal preservation. The composition of the central and regional regulations based on the legislative hierarchy Article 7 paragraph one Law No. 12 of 2011 concerning the establishment of legislation. Besides, the Andong operational distribution data collected from the City Transportation Agency. This data is used to assess the operational layout of Andong to the land function. Data analysis in the research uses descriptive analysis.

\section{The operational distribution of andong}

Figure 2 presents the operational distribution of andong (data source: Yogyakarta of City Transportation Agency, 2017). The operational distribution of andong mostly operates Malioboro road. Andong who operates in the region Malioboro is andong tour. [17]. It's known that the highest artificial tourism object visited by tourists is Malioboro $20.29 \%$ (domestic tourists) and $34.45 \%$ (foreign tourists). [16]. The spatial layout of Yogyakarta Malioboro street is a city line implies the philosophical image and cultural heritage.[14]. Malioboro is a tourist area located at Yogyakarta, [18] tourism and cultural development areas.[19]. Besides, the area is famous for its Malioboro angkringan and street vendors, [20], and shopping centres [21]. The Malioboro area developed for cultural and shopping areas.[22]. Malioboro is the street or axis the imaginary line of Yogyakarta Palace, [23] also called the philosophical axis [24]. Yogyakarta Palace is a building characteristic of the city, implying the image of historical heritage buildings and is a passive tourism image.[25]. Yogyakarta Palace is one of the cultural centres in Java, founded by Sultan Hamengku Buwana I. The form of culture in the palace consists of thought, philosophy, and mythology in its development. [26]. 


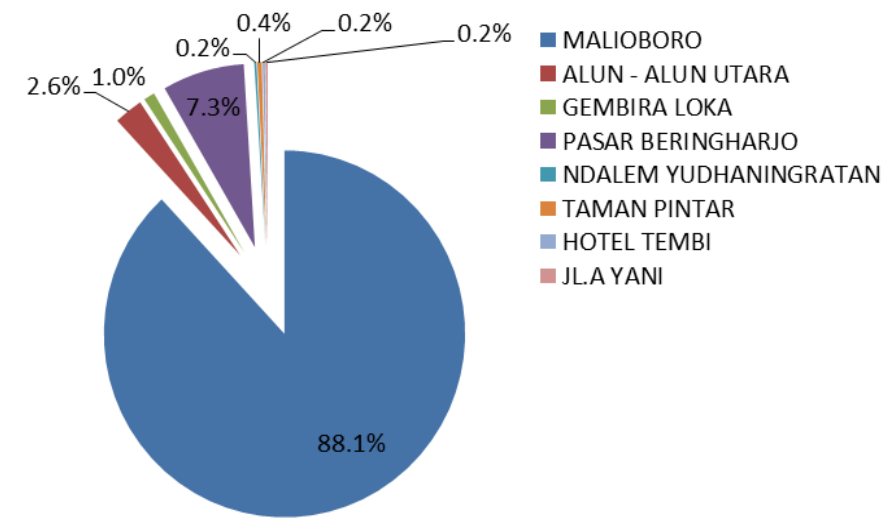

Fig. 2. Operational distribution of andong (data source: Yogyakarta Transportation Department, 2017).

Andong operates around the Beringharjo market. The beringharjo market is a city point implies a cultural image of economic activity [25]. Besides andong operates in the northern square. North Square is a place for traditional ceremonies such as grebeg and sekaten. The grebeg ceremony associated with the sultan's obligation to spread and protect the religion of Islam. While sekaten is an event to commemorate the birthday of the Prophet Muhammad [27]. In the spatial of Yogyakarta northern and south square as a city point, implies a cultural image, an image of active and passive tourism activities [25]. Other operations spread on Gembiraloka. Gembiraloka is a zoo as a city point implies a natural image [25]. Ndalem Yudhaningratan, Ndalem built under the reign of Sultan Hamengkubuwono VII. Operates at Taman Pintar at where is a recreational park [25], developed for educational tourism [28]. Operates in Hotel Tembi located in Bantul and Ahmad Yani street. Ahmad Yani street at spatial planning along with Malioboro road directed to an area of a pedestrian [25].

Tourism Office of Yogyakarta Province in preparing master plan and detail of area, planning development of traditional transportation mode as the shuttle: connecting between tourist attractions and tourism facilities. [22]. Based on the operation distribution, andong operates at the tourist attractions and connect to leading tourist attractions in Yogyakarta.

\section{Organizing Traditional Mode}

Organizing the traditional mode governed by the law to ensure the proper conduct of rules guaranteed safety and traffic safety. Based on Law no 22 of 2009, the implementations of traditional vehicles are handed over to the region according to their needs. The local government determines the arrangement, control and application of traditional modes according to their needs. The suitability of national and local regulations bring into traditional safe mode required. Figure 3 presented the regulation of the implementation of the traditional modes centre to the region especially in the study area, Yogyakarta.

For the restrictions on the number of vehicles, aims to prevent the entry of traditional vehicles outside the region to Yogyakarta and related to the operational legality. The rule expected to facilitate the arrangement, control and supervision of traditional vehicle operations. Subsequently presented the scheme of traffic safety rules, traffic planning and management as well as the preservation of modes in figures 4 , 5 and 6.

Technical specifications and physical conditions in the field andong known to have been according to the rules. [29]. Yogyakarta local government does not prohibit andong operate in corridors but more concerned with parking problems. Good cooperation between government agencies is needed. Tourism and cultural agencies have been managing the use of traditional modes as a tourist attraction. Meanwhile, the Yogyakarta Transportation Agency has conducted supervision and protection on the safety and operational modes.

Based on in-depth interviews it is known that horse carriage is not only a means of transportation but also as a culture. The habits handed down by the nobles copied by the general public. The public replicates the shape of the vehicle to be simpler and affordable in the cost of making like its current form. Based on interviews with a coachman, it is known that the coachman would not change the shape of the train according to the standards of the ancestors. The regional government through the established regulations seeks to preserve modes by paying attention to the continuity of modes and coachmen.

\section{InStitutional TRADitional Mode}

A highly complex transport system involving public and private sectors, operators and travellers. Institution regulations are required because socially and politically the rules shape the actions and behaviours enforced by the Government. [30]. Rules and enforcement needed to address the diversity of institutions and common goals. [31]. Informal operator arrangement should do at all modes. [32]. Effective urban public transport regulations require a clear framework to guide governments, cities and other stakeholders and work together on implementing traffic regulations. [33].

Institutions as the structure of social rules divided within formal and informal forms. The movement towards sustainable transport influenced by institutional conditions. [34]. The grouping of formal and informal actors translated into policies between government institutions operating at various geographical scales. [35]. Paguyuban or Gemeinschaft is ontologically called postmodernism as one of local wisdom, that is, the social reality in a city in a developing country where urban planners and designers should pay attention to successful urban solutions acceptable to many layers of the population in the city. [36]. In Yogyakarta, Paguyuban andong is an informal organization of the coachman andong. Maslow's motivational theory explains the five hierarchies of needs. The hierarchy includes physiological needs, safety, social, achievement, and self-actualization. [37], [38].

Paguyuban andong is under the auspices of Pordasi (Association of Indonesian Equestrian Sports). Members of the community 538 people scattered from all areas of Yogyakarta and formed 16 groups of community andong. The names of the groups based on the operational premises andong. (Interview Chairman of Paguyuban Kusir Andong 
DIY, Purwanto, 2018). Joining a member of the association is a requirement of operating andong. (interview Sumardi, coachman andong, 2018). The coachman must be joined on one of the existing paguyuban and have the member card of the community. (Waridi, coachman andong, 2018). Addition, the paguyuban share information when there are orders from the hotel or tourists to use andong in the tour. In low-income groups, there is an economic motivation to join and share the economy. In low-income groups, there is an economic motivation to join and share the economy. [39]. There are unwritten rules in the community of andong who must obey its members, including: 1). The number of andongs cannot add; 2). Horses should not feed on Jalan Malioboro; 3). To maintain the cleanliness of pockets of faeces installed at home; 4). The age of the coachman must be adult shown with the ownership of ID card; 5). The coachman who operates on Jl Malioboro is required to bring perfume; 6). The coachman must have SIO KTB and KTA (membership card); 7). Coachman may be a member of one of the group cannot follow two groups.

Rules applied in three ways through control quality, quantity and cost. [33]. Related to the quality control and quantity of the traditional mode of operation, the Transportation Department of Yogyakarta in maintaining sustainable transportation through andong operational order throughout Yogyakarta. Its role is the operational regulation in the form of issuance of Non-Motorized Vehicle Operation Permit (SIOKTB) and Motor Vehicle Registration Number (TNKTB), reflector and identity sticker installed in the passenger seat.

Local governments do not set tariff rules for traditional modes. Travel costs set by agreement between tourists and coachmen. The tariffs of ordinary days are cheaper than holidays. A destination of the trip is travelling around Malioboro, palace or to craft and food centres. There is an unwritten cooperation relationship between the coachman and the typical craft/food entrepreneur. The coachmen who deliver tourists get a bonus of up to $20 \%$ of the price. The form of partnership is independent means not facilitated by local government. The scheme of institutional relationships in maintaining order and arrangement of traditional vehicles in supporting tourism acts presented in Figure 7.

\section{CONCLUSIONS}

The importance of the regulation aspect is as a form of protection and legality in the implementation of the traditional mode in Indonesia. The Regulations serve as a reference for the implementation of easy implementation and supervision. The synchronization and mutual support of central and local policies make the regulation workable. So a proper regulatory framework is required. The law entirely handed over the administration of traditional modes to the regions according to their needs. Province of Special Region of Yogyakarta in preserving cultural heritage in the form of traditional vehicle andong empowered in supporting tourism culture city. Related aspects of safety and security Local Government has set about the technical specifications of vehicles, operational permits and vehicle number marks. addition, the laws and regulations issued as legality aspects of traditional vehicles. So the traditional vehicle operators feel the security and recognition as well as the same rights in running the business of serving passengers. It's important that regulations directed to everyone indiscriminately. The efforts of the Government of Yogyakarta in maintaining and empowering the sustainability of the mode and its preservation through the arrangement, order and supervision as well as utilizing it as a tourist attraction should be imitated by other regions in Indonesia in maintaining the nation's cultural heritage and incorporate traditional transportation in the dynamic city transportation system.

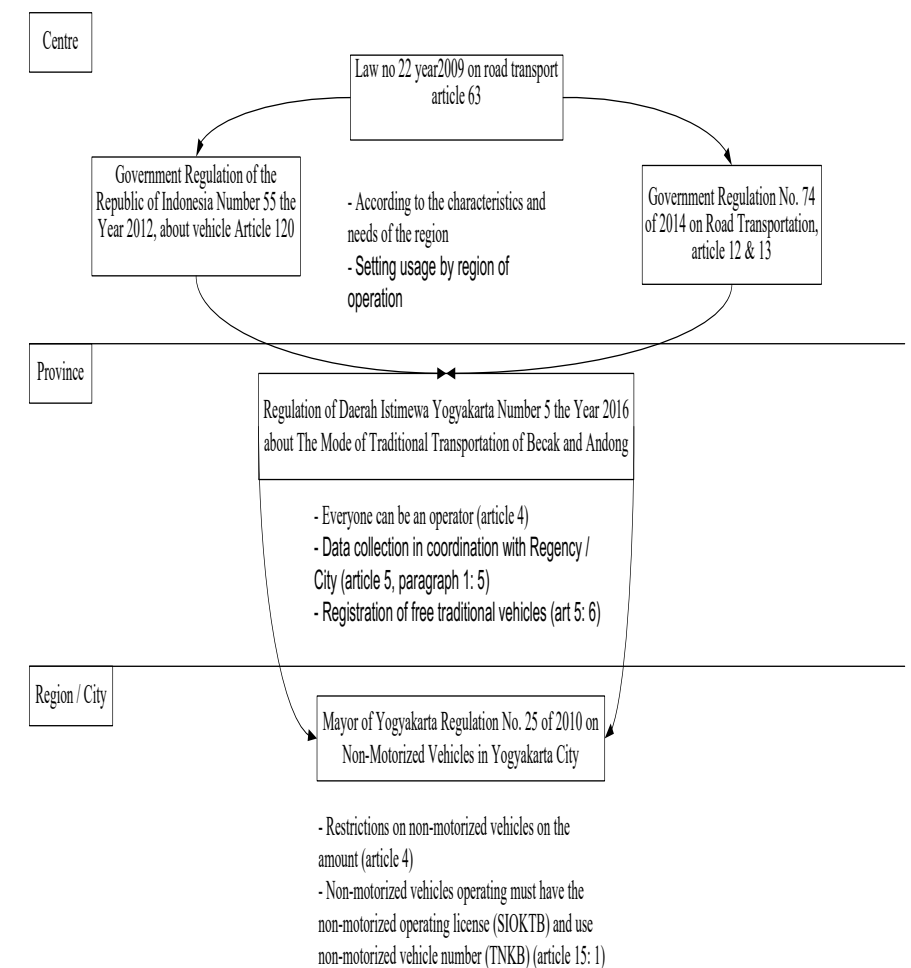

Fig. 3. The scheme of regulation of the implementation of traditional vehicles in Yogyakarta 


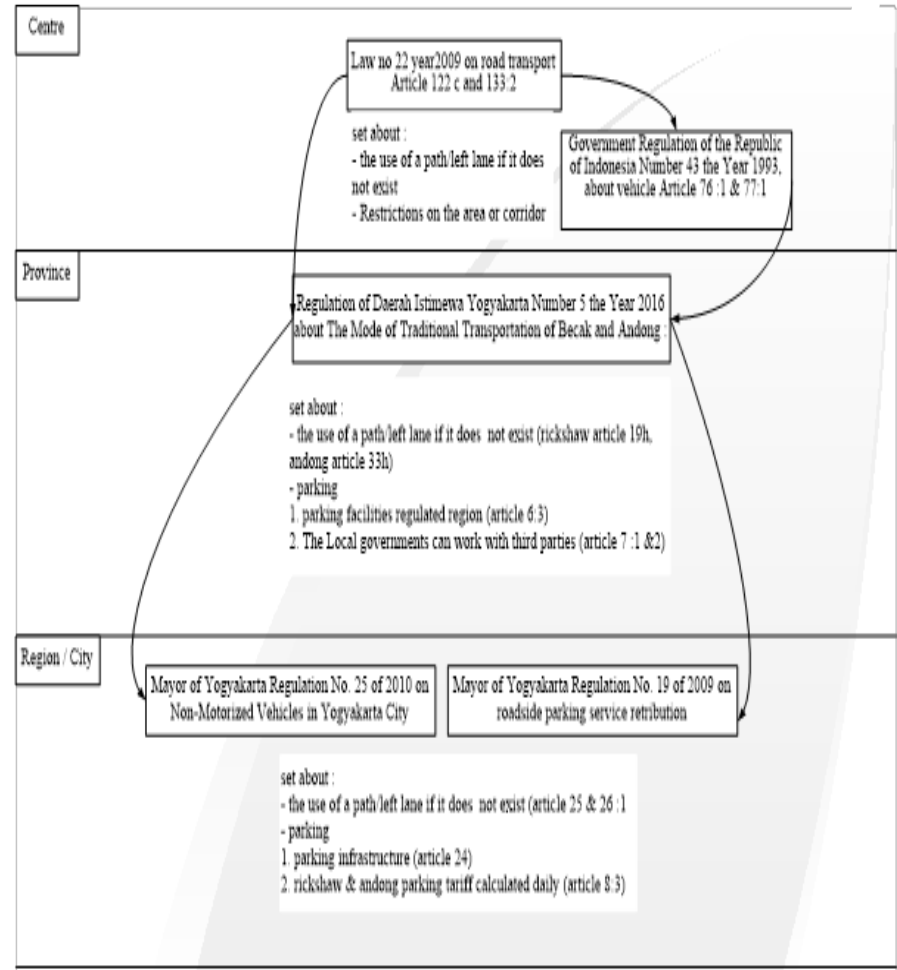

Fig. 4. Planning and traffic management for traditional modes in Yogyakarta

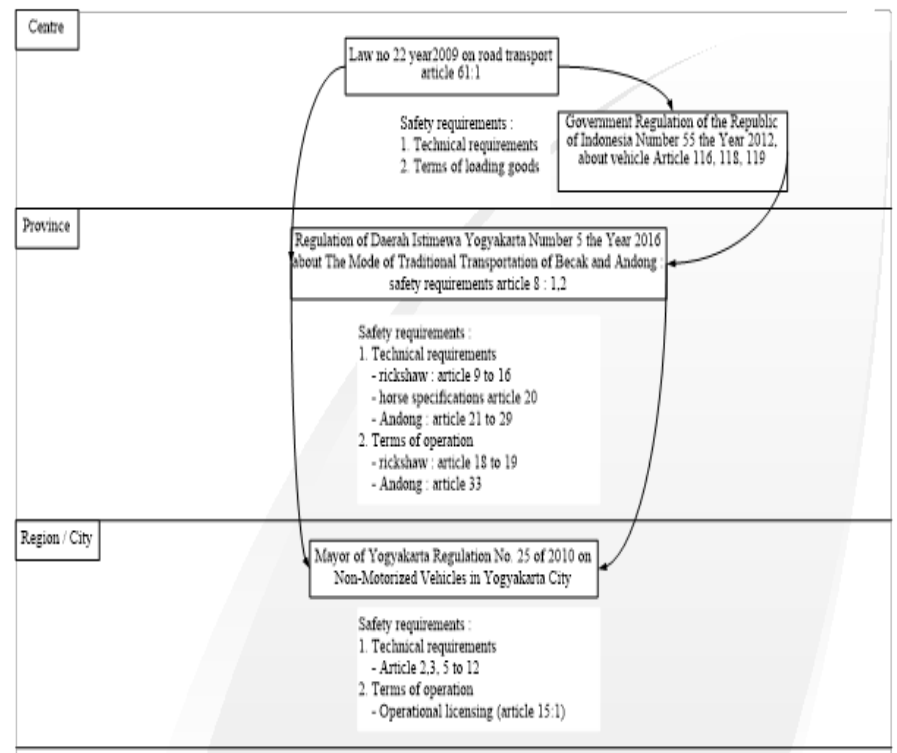

Fig. 5. Safety requirements for traditional modes in Yogyakarta

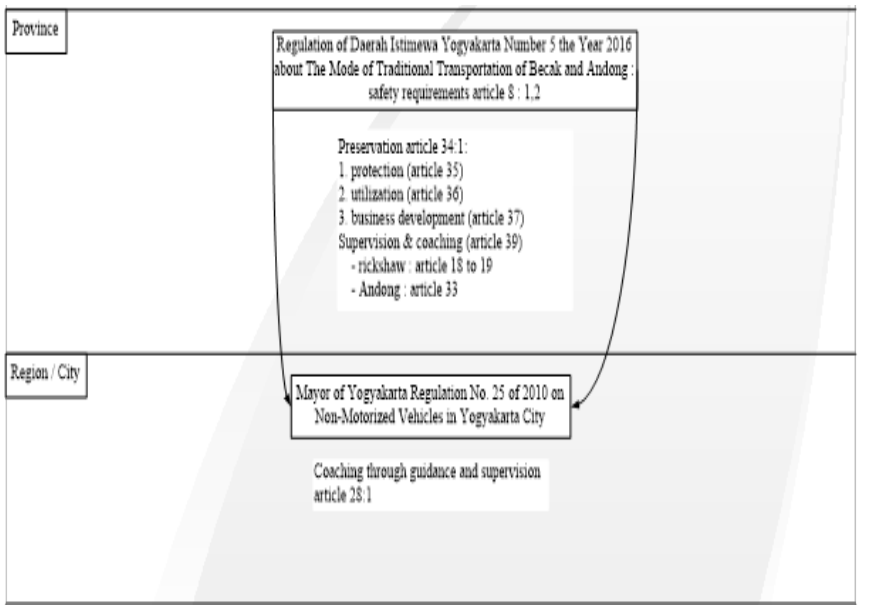

Fig. 6. The preservation of traditional mode in Yogyakarta

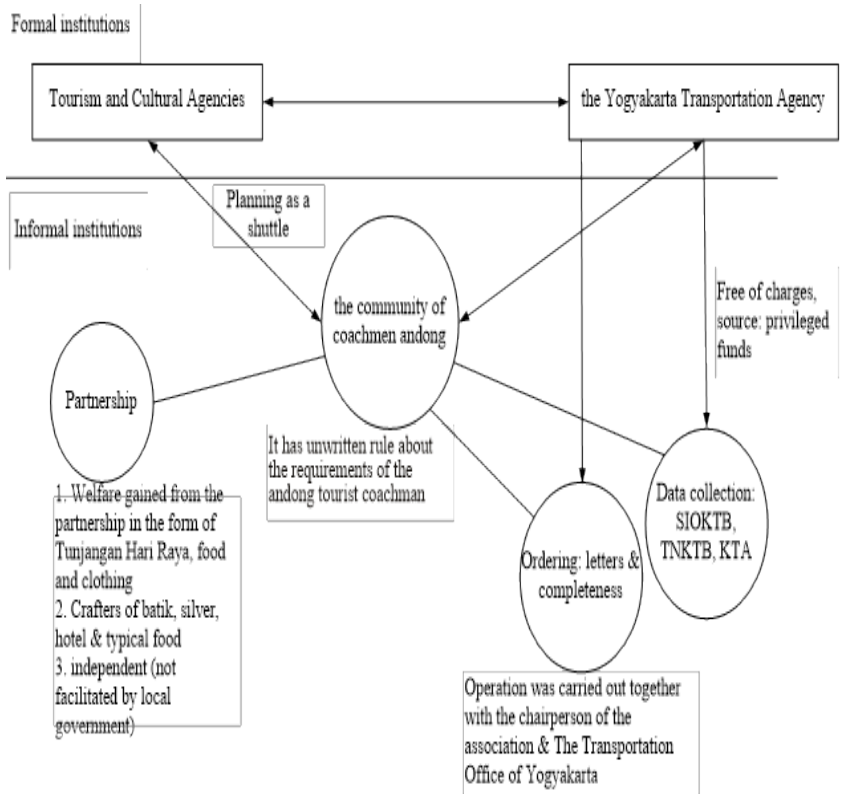

Fig. 7. The scheme of institutional relationships in maintaining order and arrangement of traditional mode in supporting tourism in Yogyakarta.

\section{REFERENCES}

[1] T. Litman, "Evaluating non-motorized transportation benefits and costs," Transp. Res. Rec., pp. 134-140, 2012.

[2] W. Wey and Y. Chiu, "Assessing the walkability of pedestrian environment under the transit-oriented development," Habitat Int., vol. 38, pp. 106-118, 2013.

[3] Kemenhub dan GIZ, "Program transportasi perkotaan berkelanjutan indonesia / sustainable urban transport programme Indonesia," 2014.

[4] A. Pramono, "Pengelolaan transportasi ramah lingkungan di kota Mataram," Universitas Dipenogoro, 2008.

[5] M. I. Adiakurnia, "Delman segera beroperasi, ini kisah perjalanan delman di Monas," Kompas, Jakarta, 23-Nov-2017, 2017.

[6] D. O. Purba, "Penghapusan operasional becak di Jakarta, dari 1936 hingga kini,” Kompas, Jakarta, 15-Jan-2018, 2018.

[7] Presiden Republik Indonesia, Peraturan Pemerintah Republik Indonesia nomor 55 tahun 2012 tentang kendaraan, vol. 2, 
2012.

[8] Presiden Republik Indonesia, "UU nomor 22 tahun 2009 tentang lalu lintas dan angkutan jalan," 2009.

[9] B. Mao, H. Chen, and S. Chen, "Sustainability assessment of speed regulation of urban traffic," IATSS Res., vol. 26, no. 2, pp. 18-24, 2002.

[10] B. T. . Soegijoko, "Intermediate public transportation for developing countries case study: Bandung, Indonesia," Massachusetts Institute of Technology, 1982.

[11] M. Kumar, "Sustainable urban transport indicators," 2014.

[12] T. Litman, "Well measured developing indicators for sustainable and livable transport planning," 2016.

[13] P. Zito and G. Salvo, "Toward an urban transport sustainability index: An European comparison," Eur. Transp. Res. Rev., vol. 3, no. 4, pp. 179-195, 2011.

[14] Gubernur Daerah Istimewa Yogyakarta, Peraturan Daerah Daerah Istimewa Yogyakarta nomor 5 tahun 2016 tentang moda transportasi tradisional becak dan andong. 2016.

[15] Badan Pusat Statistik, "Daerah Istimewa Yogyakarta dalam angka 2015,” BPS Drh. Istimewa Yogyakarta, pp. 625, 2015.

[16] Dinas Pariwisata DIY, "Laporan akhir analisa pembelanjaan wisatawan 2017," 2017.

[17] A. Sa'diyah, "Eksistensi andong sebagai daya tarik wisata di kawasan Malioboro Yogyakarta," in Budaya Lokal dalam Perkembangan Pariwisata di Yogyakarta, H. Y. A. Murdiyastomo, Ed. Penerbit Ilmu Sejarah FIS UNY, pp. 70-79, 2017.

[18] Y. Trisnawati and B. Sunaryo, "Keberadaan moda transportasi umum tidak bermotor dalam mendukung aktivitas pariwisata di kawasan Malioboro, Yogyakarta," J. Tek. PWK, vol. 3, no. 4, pp. 1013-1024, 2014.

[19] Walikota Yogyakarta, Peraturan Walikota Yogyakarta nomor 92 tahun 2009 tentang pembentukan, susunan, kedudukan, fungsi dan rincian tugas unit pelaksana teknis pengelolaan kawasan Malioboro pada dinas pariwisata dan kebudayaan kota Yogyakarta. 2009.

[20] H. Suyuti, "Yogyakarta city report for integrated conference of BAQ 2014 and intergovernmental," Eighth Reg. EST Forum Asia, no. November, (2014).

[21] H. Dahles and K. Bras, "Entrepreneurs in romancetourism in Indonesia,” Ann. Tour. Res., vol. 26, no. 2, pp. 267-293, 1999.

[22] Dinas Pariwisata DIY, "Penyusunan rencana induk dan rencana detail kawasan strategis pariwisata nasional kota Yogyakarta dan sekitarnya," 2016.

[23] Dinas Pariwisata Daerah Istimewa Yogyakarta, "Yogyakarta city of philosophy," 2017.

[24] Suryanto, A. Djunaedi, and Sudaryono, "Aspek budaya dalam keistimewaan tata ruang kota Yogyakarta," J. Perenc. Wil. dan Kota, vol. 26, no. 3, pp. 230-252, 2015.

[25] Walikota Yogyakarta, Peraturan Daerah Kota Yogyakarta no 2 tahun 2010 tentang rencana tata ruang wilayah kota Yogyakarta Tahun 2010-2029, 2010.

[26] F. Pribadi, "Keraton Yogyakarta sebagai akar budaya bangsa Indonesia," 2014.

[27] Https://gudeg.net/direktori/345/riwayat-singkat-perayaansekaten.html, "Riwayat singkat perayaan sekaten."

[28] A. N. Abrar, "Toko buku di komplek taman pintar sebagai bagian dari sebuah paket objek rekreasi," in Jurnal Penelitian Bappeda Kota Yogyakarta, vol. 10, no. 4, pp. 30-40, 2007.

[29] Risdiyanto, I. J. Koenti, and E. U. Hasanah, "Karakteristik pengemudi, layanan, serta fisik becak dan andong di DIY," Pros. Semin. Nas. Tek. Sipil V, pp. 91-99, 2015.

[30] P. Rietveld and R. Stough, "Institutions, regulations and sustainable transport: A cross-national perspective," Transp. Rev., vol. 24, no. 6, pp. 707-719, 2004.

[31] R. Khanna, S. Singh, R. Arora, H. Chahal, A. Khan, A. Gupta,
M. Gupta, and T. Khanam, "Analysing the role of government regulations \& intervention in e-rickshaw industry of Delhi," Int. J. Manag. Appl. Scinces, vol. 2, no. 12,Dec-2016, pp. 54-59, 2016.

[32] A. Golub, R. Balassiano, A. Araújo, and E. Ferreira, "Regulation of the informal transport sector in Rio de Janeiro, Brazil: Welfare impacts and policy analysis," Transportation (Amst)., vol. 36, no. 5, pp. 601-616, 2009.

[33] M. Sohail, D. A. C. Maunder, and S. Cavill, "Effective regulation for sustainable public transport in developing countries," Transp. Policy, vol. 13, no. 3, pp. 177-190, 2006.

[34] P. Rietveld and R. Stough, "Institutions , regulations and sustainable transport, a review," Eur. J. Transp. Infrastruct. Res., vol. 6, no. 1, pp. 99-112, 2006.

[35] M. Jenkins, "Knowledge and practice mobilities in the process of policy-making: The case of UK national well-being statistics," Polit. Geogr., vol. 56, pp. 24-33, 2017.

[36] R. Soesilo, "Local wisdom as the ontological foundation to postmodern urban-design in a developing country," Int. Rev. Spat. Plan. Sustain. Dev., vol. 2, no. 4, pp. 54-67, 2014.

[37] R. J. Taormina and J. H. Gao, "Maslow and the motivation hierarchy: measuring satisfaction of the needs," Am. J. Psychol., vol. 126, no. 2, pp. 155-177, 2013.

[38] R. Yao, E. Kwesi, and C. Adjei, "Public transport mode preferences of international tourists in Ghana: Implications for transport planning," Travel Behav. Soc., vol. 11, no. June 2017, pp. 1-8, 2018.

[39] L. Böcker and T. Meelen, "Sharing for people, planet or profit? Analysing motivations for intended sharing economy participation," Environ. Innov. Soc. Transitions, vol. 23, pp. 28-39, 2017. 